\title{
A PCR-RFLP Assay for the A716T Mutation in the WFS1 Gene, a Common Cause of Low-Frequency Sensorineural Hearing Loss
}

\author{
THERU A. SIVAKUMARAN and MARCI M. LESPERANCE
}

\begin{abstract}
Nonsyndromic low-frequency sensorineural hearing loss (LFSNHL) is an unusual type of hearing loss that affects frequencies at $2,000 \mathrm{~Hz}$ and below. Recently, we reported five different heterozygous missense mutations in the Wolfram syndrome gene, WFS1, found to be responsible for LFSNHL in six families. One of the five mutations, A716T, may be a common cause of LFSNHL, as it has been reported in three families to date (Bespalova et al., 2001; Young et al., 2001). We have developed a PCR-based restriction fragment-length polymorphism (RFLP) assay to detect the A716T mutation in a simple, specific test. This method was evaluated with DNA samples from a family in which the A716T mutation was segregating with LFSNHL. This simple assay successfully detected the presence of the A716 Tutation in all of the individuals predicted to be affected, based on audiologic results. Therefore, this assay can be routinely used for initial screening of the A716 T mutation in patients with LFSNHL, before screening the entire coding region of the WFS1 gene.
\end{abstract}

\section{INTRODUCTION}

$\mathbf{N}$ ONSYNDROMIC LOW-FREQUENCY SENSORINEURAL HEARING LOSS (LFSNHL) is an unusual type of hearing loss affecting the low frequencies, $2000 \mathrm{~Hz}$ and below, which worsens over time, without progressing to profound deafness (Vanderbilt Hereditary Deafness Study Group, 1968; Lesperance $e t$ al., 1995; Kunst et al., 1999). Although over 70 loci responsible for nonsyndromic sensorineural hearing loss have been mapped to date, only two chromosomal locations, 5q31 (DFNA1) (Lynch et al., 1997) and 4p16 (DFNA6/14/38) (Lesperance $e t$ al., 1995; Van Camp et al., 1999; Young et al., 2001) are associated with autosomal dominant LFSNHL. Recently, mutations in the Wolfram syndrome gene (WFS1), which is mutated in the recessively inherited Wolfram syndrome (an association of diabetes insipidus, diabetes mellitus, optic atrophy, and deafness), were found in families with LFSNHL (Bespalova et al., 2001; Young et al., 2001).

One mutation, 2316G $\rightarrow$ A, also known as A716T (GenBank AF084481), has been found to segregate in three of seven LFSNHL families with heterozygous WFS1 mutations. Because this mutation occurs in a $\mathrm{CpG}$ dinucleotide (Cooper and Yous- soufian, 1988) and appears to have arisen independently in different families (Bespalova et al., 2001), we hypothesize that this mutation may be a common cause of LFSNHL. This mutation can be detected by DNA sequencing or screened by methods such as denaturing high-performance liquid chromatography (DHPLC), or single-stranded conformation polymorphism analysis (SSCP). DNA sequencing alone is not optimal for detection of the A716T mutation, because the overlapping peaks of a heterozygous mutation are easily missed. Single nucleotide polymorphisms (SNPs) occur frequently in the coding region of the WFS1 gene, with one variant every $66 \mathrm{bp}$, on average (T.A. Sivakumaran and M.M. Lesperance, unpublished data). Thus, DHPLC and SSCP are inefficient methods for screening WFS1, because multiple variants in addition to the one of interest will be identified. Using DNA sequencing to distinguish between polymorphisms and disease-causing mutations detected by SSCP or DHPLC adds time and expense to the mutation screening process.

Because the A716T mutation abolishes a site for the restriction endonuclease Hae II, a PCR-based RFLP assay can be used to identify the alteration in a single test. In this way, the expense, labor, and difficulties associated with interpretation of

Department of Otolaryngology-Head and Neck Surgery, University of Michigan, Ann Arbor, MI 48109. 
DNA sequencing can be avoided. Therefore, we developed a PCR-RFLP assay to screen for the A716T mutation and evaluated its sensitivity in a LFSNHL family known to segregate this mutation.

\section{MATERIALS AND METHODS}

\section{Subjects}

DNA sequence analysis identifying the A716T mutation in affected individuals from Family 35 has been previously reported (Bespalova et al., 2001). The current study included 26 family members (9 affected and 17 unaffected relatives).

\section{$P C R$}

Genomic DNA was prepared using standard methodology. PCR reactions consisted of $40 \mathrm{ng}$ of genomic DNA, $1 \times \mathrm{PCR}$ buffer II (Perkin Elmer, Foster City, CA), $1.5 \mathrm{mM} \mathrm{MgCl}$ (Perkin Elmer, Foster City, CA), $0.2 \mathrm{mM}$ of each dNTP (GibcoBRL, Rockville, MD), $0.5 \mu M$ of each forward and reverse primer, and $0.25 \mathrm{U}$ of Amplitaq Gold DNA Polymerase (Perkin Elmer, Foster City, CA) in a total volume of $10 \mu \mathrm{l}$. A 573-bp fragment of exon 8 was amplified using the following primers (Strom et al., 1998):

\section{Forward primer 8.5F: ATCCTGGTGTGGCTCACG} Reverse primer 8.6R: GCTGAACTCGATGAGGCTG

PCR reactions were carried out in a thermal cycler (MJ Research, Waltham, MA) with an initial denaturation step at $95^{\circ} \mathrm{C}$ for $10 \mathrm{~min}$, then 35 cycles of $93^{\circ} \mathrm{C}$ for $1 \mathrm{~min}, 56^{\circ} \mathrm{C}$ for $30 \mathrm{sec}$, and $72^{\circ} \mathrm{C}$ for $30 \mathrm{sec}$ followed by extension at $72^{\circ} \mathrm{C}$ for $10 \mathrm{~min}$.

\section{Restriction enzyme assay}

Detection of the A716T mutation was carried out by digestion of the PCR products with Hae II. The PCR fragment amplified from the wild-type allele contains two Hae II sites at positions 242 and 455, whereas the mutant A716T has only one restriction site at position 455 . The second restriction site in the fragment serves as an internal control for incomplete digestion. The enzymatic digestion consisted of $10 \mu \mathrm{l}$ of PCR product, $2.5 \mathrm{U}$ of restriction endonuclease Hae II (Gibco-BRL, Rockville, MD), and $1 \times$ reaction buffer in a total volume of $15 \mu \mathrm{l}$ reaction incubated at $37^{\circ} \mathrm{C}$ for $6 \mathrm{hr}$. The products were then resolved on a $2 \%$ agarose gel, stained with ethidium bromide and detected on a UV transilluminator.

\section{RESULTS}

Hae II digestion of the PCR product amplified from the wildtype allele yields three bands of 242, 213, and 118 bp (Fig. 1). The A716T mutation abolishes the restriction site for Hae II at position 242, and the digestion reaction results in two fragments of $455 \mathrm{bp}$ and $118 \mathrm{bp}$. DNA samples from individuals heterozygous for the A716 mutation yield four bands of 455, 242, 213 , and $118 \mathrm{bp}$. As predicted, all unaffected individuals and controls were homozygous for the normal allele, while affected individuals were heterozygous for the A716T mutation.

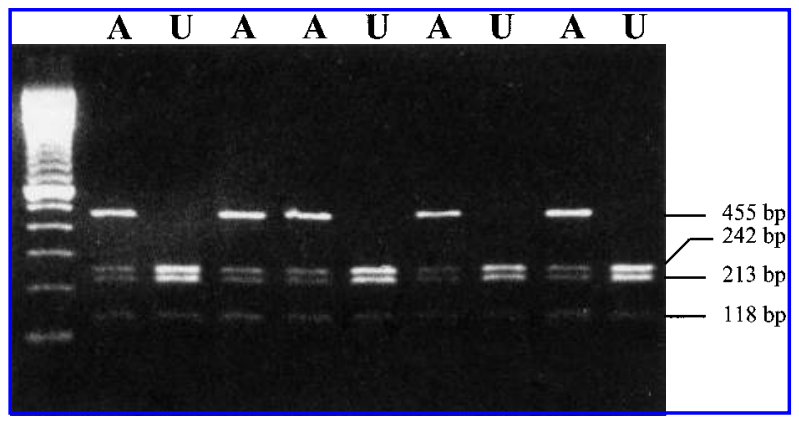

FIG. 1. Restriction enzyme analysis of PCR products for the detection of A716T missense mutation in WFS1 gene in a family with LFSNHL. The A716T mutation abolishes one of the two restriction sites for Hae II. As a result, DNA samples from all the affected individuals (A) yield four bands (455, 242, 213, and $118 \mathrm{bp}$ ), while DNA samples from the unaffected individuals (U) yield three bands (242, 213, and $118 \mathrm{bp}$ ).

\section{DISCUSSION}

The A716T mutation has been described in 3 of 7 families reported to date with LFSNHL attributable to WFS1, a common cause of LFSNHL (Bespalova et al., 2001; Young et al., 2001). DNA sequencing may miss heterozygous mutations when overlapping peaks are difficult to detect and/or interpret on the chromatogram. SSCP and DHPLC may be efficient when the number of variants is low, but these methods are not as useful for screening the WFS1 gene, which has a large number of SNPs in its coding sequence. While none of the $>100$ SNPs found so far affect this site, it is theoretically possible that a mutation other than A716T in the 4 bases of the Hae II site could abolish the restriction site. DNA sequencing can be used to confirm positive results on the PCR-RFLP assay in the same way that recognition of the variant sequence by a restriction endonuclease confirms the DNA sequence interpreted from the chromatogram.

The PCR-RFLP assay described herein is a simple and rapid test that successfully identified the presence or absence of the A716T mutation in all the family members analyzed. The second obligatory restriction site serves as an internal control, such that incomplete digestion will not be misinterpreted as heterozygosity for A716T. Therefore, this assay may be useful for initial screening of the A716T mutations in families with LFSNHL before screening the entire gene for mutations.

\section{ACKNOWLEDGMENTS}

We thank Drs. Suzanne Leal, Margaret Lomax, and Margit Burmeister.

\section{REFERENCES}

BESPALOVA, I.N., VAN CAMP, G., BOM, S.J.H., BROWN, D.J., CRYNS, K., DE WAN, A.T., ERSON, A.E., FLOTHMANN, K., KUNST, H.P.M., KURNOOL, P., SIVAKUMARAN, T.A., CRE- 
MERS, C.W.R.J., LEAL, S.M., BURMEISTER, M., and LESPERANCE, M.M. (2001). Mutations in the Wolfram syndrome 1 gene (WFSl) are a common cause of low frequency sensorineural hearing loss. Hum. Mol. Genet. 10, 2501-2508.

COOPER, D.N., and YOUSSOUFIAN, H. (1988). The CpG dinucleotide and human genetic disease. Hum. Genet. 78, 151-155.

KUNST, H., MARRES, H., HUYGEN, P., VAN CAMP, G., JOOSTEN, F., and CREMERS, C. (1999). Autosomal dominant nonsyndromal low-frequency sensorineural hearing impairment linked to chromosome 4p16 (DFNA14): statistical analysis of hearing threshold in relation to age and evaluation of vestibulo-ocular functions. Audiology 38, 165-173.

LESPERANCE, M.M., HALL, J.W., BESS, F.H., FUKUSHIMA, K., JAIN, P.K., PLOPLIS, B., SAN AGUSTIN, T.B., SKARKA, H., SMITH, R.J.H., WILLS, M., and WILCOX, E.R. (1995). A gene for autosomal dominant nonsyndromic hereditary hearing impairment maps to 4p16.3. Hum. Mol. Genet. 4, 1967-1972.

LYNCH, E.D., LEE, M.K., MORROW, J.E., WELCSH, P.L., LEON, P.E., and KING, M.C. (1997). Nonsyndromic deafness DFNA1 associated with mutation of a human homolog of the Drosophila gene diaphanous. Science 278, 1315-1318.

STROM, T.M., HÖRTNAGEL, K., HOFMANN, S., GEKELER, F., SCHARFE, C., RABL, W., GERBITZ, K.D., and MEITINGER, T. (1998). Diabetes insipidus, diabetes mellitus, optic atrophy and deafness (DIDMOAD) caused by mutations in a novel gene (wolframin) coding for a predicted transmembrane protein. Hum. Mol. Genet. 7, 2021-2028.

VAN CAMP, G., KUNST, H., FLOTHMANN, K., MCGUIRT, W.,
WAUTERS, J., MARRES, H., VERTREKEN, M., BESPALOVA, I.N., BURMEISTER, M., VAN DE HEYNING, P.H., SMITH, R.J.H., WILLEMS, P.J., CREMERS, C.W.R.J., and LESPERANCE, M.M. (1999). A gene for autosomal dominant hearing impairment (DFNA14) maps to a region on chromosome 4p16.3 that does not overlap the DFNA6 locus. J. Med. Genet. 36, 532-536.

VANDERBILT HEREDITARY DEAFNESS STUDY GROUP. (1968). Dominantly inherited low-frequency hearing loss. Arch. Otolaryngol. 88, 242-250.

YOUNG, T.L., IVES, E., LYNCH, E., PERSON, R., SNOOK, S., MACLAREN, L., FERNANDEZ, B., LEE, M.K., and KING, M.C. (2001). Nonsyndromic progressive hearing loss DFNA38 is caused by heterozygous missense mutation in the Wolfram syndrome gene WFS1. Hum. Mol. Genet. 10, 2509-2514.

Address reprint requests to: Dr. Marci M. Lesperance Division of Pediatric Otolaryngology Department of Otolaryngology_Head and Neck Surgery F6905 Mott, Box 0241 1500 East Medical Center Drive Ann Arbor, MI 48109-0241

E-mail: lesperan@umich.edu

Received for publication December 7, 2001; accepted June 5, 2002 . 